IRA-International Journal of Management \&

QUARTERLY

Social Sciences

ISSN 2455-2267; Vol.15, Issue 04 (July-September, 2019)

Pg. no. 99-110.

Institute of Research Advances

http://research-advances.org/index.php/RAJMSS

\title{
An Analytical Study on Harry Markowitz Portfolio Construction of Selected Industries
}

\author{
Vishweswarsastry V.N. ${ }^{1 \#}$ \& Dr Binoy Mathew ${ }^{2}$ \\ ${ }^{1}$ Research Scholar-VTU, Department of PG-Commerce, Presidency College, Kempapur, \\ Bengaluru-560024, India. \\ ${ }^{2}$ Associate Professor, Dept. of MBA, Visvesvaraya Technological University, Centre for Post \\ Graduate Studies, Bangalore Region, Visvesvaraya Institute of Advanced Technologies (VIAT), \\ Muddenahalli, Chikkaballapur Dist., Karnataka State - 562101, India \\ \# corresponding author. \\ Type of Work: Peer Reviewed. \\ DOl: http://dx.doi.org/10.21013/jmss.v15.n4.p2
}

\section{How to cite this paper:}

Vishweswarsastry V.N., Mathew, B. (2019). An Analytical Study on Harry Markowitz Portfolio Construction of Selected Industries. IRA-International Journal of Management \& Social Sciences (ISSN 2455-2267), 15(4), 99-110. doi:http://dx.doi.org/10.21013/jmss.v15.n4.p2

(C) Institute of Research Advances.

\section{(cc)) BY-NC}

This work is licensed under a Creative Commons Attribution-Non Commercial 4.0 International License subject to a proper citation to the publication source of the work.

Disclaimer: The scholarly papers as reviewed and published by the Institute of Research Advances (IRA) are the views and opinions of their respective authors and are not the views or opinions of the IRA. The IRA disclaims of any harm or loss caused due to the published content to any party.

Institute of Research Advances is an institutional publisher member of Publishers International Linking Association Inc. (PILA-CrossRef), USA. The institute is an institutional signatory to the Budapest Open Access Initiative, Hungary advocating the open-access of scientific and scholarly knowledge. The Institute is a registered content provider under Open Access Initiative Protocol for Metadata Harvesting (OA/-PMH).

The journal is indexed \& included in WorldCat Discovery Service (USA), CrossRef Metadata Search (USA), WorldCat (USA), OCLC (USA), Open J-Gate (India), EZB (Germany) Scilit (Switzerland), Airiti (China), Bielefeld Academic Search Engine (BASE) of Bielefeld University, Germany, PKP Index of Simon Fraser University, Canada. 


\begin{abstract}
Risk and return are two faces of the same coin, Investments made by the investors are certain whereas the returns expected are uncertain when measured known as risk. The primary objective of the paper is to study the risk and return measures available for decision making, secondly to apply the techniques of beta and standard deviation for analyzing the risk and expected return for analyzing the return and to construct an optimal portfolio by applying Harry Markowitz portfolio construction technique. The Methodology applied is analytical and descriptive and application of Harry Markowitz portfolio Risk and Return techniques for the construction of an optimal portfolio.
\end{abstract}

Keywords: Beta, Standard deviation, Harry Markowitz, volatility, Correlation.

JEL: D53, E44, G11

\title{
Introduction
}

Risk is the uncertainty quantified and compared with the reward gained by an investor over a period of holding his shares. Risk and Return are two faces of the same coin. An investor invests in the market with an intention of returns in the near future, the investments investor does is certain whereas the returns are uncertain and when those uncertain returns are quantified it is termed as risk. There are risks which are common throughout for all the investors known as systematic and there are risks which are firm-specific or industry-specific known as unsystematic risk. The systematic risk is measured using Beta whereas the unsystematic risk is measured using Variance and standard deviation.

\section{Objectives of the Paper}

1. To study the risk and return measures available for Decision making

2. To analyze the risk through Beta and Standard deviation.

3. To correlate among various selected companies

4. To construct an optimal portfolio based on portfolio risk and return.

\section{Scope of the Study}

The study is restricted for ten industries and five companies in each industry, for a period of 6 years from Jan 2012 to Jan 2018.

\section{Review of Literature}

Dr S Poornima and Swathiga P(2017): Observed that the authors have studied the relationship between risk and return with the help of CAPM. The authors have taken five automobile and five IT companies for the study. The authors have applied the study by CAPM model and found that the automobile sector had positive returns with low risk, whereas the IT sector had shown a negative return with high risk. B.Vijayalakshmi (2017): The aim of the paper was to construct a portfolio of three sectors which includes IT, Telecommunication and automobile. The paper focuses on Risk and return of the sector by considering three companies in each sector and the methodology applied is Markowitz portfolio construction by analysis portfolio return and risk. The correlation was applied to pick the stocks based on the negative correlation as it diversifies the risk of the stocks when it is included in the portfolio. Dr M.Muthu Gopalakrishnan and Amal Vijay A K (2017): Observed from their study that as the return is high the expected risk from the asset will also be high, Investors should come to know the risk before investing in equity markets. The authors have analyzed the pharmaceutical industry which helps investors to make informed and rational investment decisions. They have used Excel for analyzing the data and their outcome of the study was sun pharmaceutical provided high returns with high market risk, they said Divi's laboratories ltd is more favourable to potential investors because it was given high return with minimal risk. Dr. Prashanth B. Ashturkar, AbdulelahMahmood A.A Bazi (2015): The authors have taken Banking sector for analyzing Risk and return relationship, the aim of the paper is to understand the economic situation of the Indian Banking system and the impact of global business environment on the risks that Indian Banks face and profit return profile for the Indian Banks in the country..Dinesh Tandon, Dr NidhiWalia (2015): The authors have analyzed the risk and return and aimed at dividend announcements as a signal and how it can be perceived by the investors in the market. They have studied the performance of 25 Indian companies in relation to its Benchmark Index and this relationship found for the period 2009-2013. The tools used were alpha, slope, and r-square and through regression, these values were obtained. Arti Sharma(2015): The study was conducted on various sectors and was found 
that the funds provide diversification within a particular sector and investing in sectoral funds is less risky than equity shares. Kolani Pamane and Anani Ekoue Vikpossi (2014): noted from the paper that the relationship between expected return and the risk-free rate is linearly related to nonreversible risk measured by its beta. This relationship according to the authors can be well studied through CAPM. The outcome of the study showed that the relationship between beta and expected return is linear and found CAPM adequately captures all the information of returns and residual variance of stocks. The results further showed that residual risk has no effect on the expected returns of the whole period and the sub-periods except 2003-2008. Dr P Vikkraman and P Varadharajan (2009): noted that the authors tried to focus on automobile Industry for their study and had studied that automobile industry multiplier effect on the growth of the country and has a capable of driving the economic growth. The objective of their paper is to maximize the expected returns for the Investments and the authors have taken the historical data for analyzing the expected returns. The authors have also analyzed the return using Alpha and risk through Beta.

\section{Research Gap}

From the above literature survey, it is evident that few companies were studied in the previous Studies. Hence this article focuses on multiple industries in analyzing the risk and return of the selected companies and portfolio risk and returns and assesses its relationship in taking Investment decision of those multiple industries.

\section{Statement of the Problem}

The stocks volatiles based on multifactor, assessing the right stocks for inclusion in the optimal basket is a necessity, also advisable to check the volatility which causes losses for the Investment made by the investors.

\section{Instruments for Analysis}

The risk of the financial assets are measured through beta, standard deviation and the return of the stocks are measured through average and Alpha to assess the risk and return of the selected securities.

Table 1: Showing the Risk and Return of the stocks from different selected sectors

\begin{tabular}{|c|c|c|c|c|c|}
\hline Sector & Company & AVERAGE & Standard Deviation & Beta & Alpha \\
\hline Pharma & Lupin & 1.22459873 & 7.784472993 & -0.01649 & 1.242158 \\
\hline Pharma & Sunpharma & 0.58051287 & 9.348751943 & 0.289418 & 0.27226 \\
\hline Pharma & Aurobindo & 3.30043262 & 12.73573834 & 0.935825 & 2.303705 \\
\hline Pharma & Cipla & 0.99457939 & 6.825331681 & 0.417873 & 0.549512 \\
\hline Pharma & Pfizer & 1.2819 & 10.46172643 & 0.162653 & 1.108618 \\
\hline Automobile & Maruti & 3.29681298 & 9.026482606 & 1.651772 & 1.537546 \\
\hline Automobile & Tata Motors & 1.27980772 & 10.29204526 & 1.663416 & -0.49186 \\
\hline Automobile & Bajaj Auto & 1.16431763 & 6.698365355 & 0.998311 & 0.101039 \\
\hline Automobile & Eicher Motors Ltd & 4.35624459 & 8.87908677 & 0.667803 & 3.644983 \\
\hline Automobile & Force Motors & 3.92336762 & 17.42761493 & 1.242609 & 2.599892 \\
\hline Banking & Axis Bank & 0.61899962 & 13.30689567 & 1.771847 & -1.26816 \\
\hline Banking & PNBank & -0.39117956 & 16.96929152 & 2.64051 & -3.20353 \\
\hline Banking & Canara Bank & 0.39788859 & 13.41921815 & 2.268453 & -2.01819 \\
\hline Banking & Vijaya Bank & 0.70050144 & 10.06252917 & 1.361569 & -0.74968 \\
\hline Banking & ICICI Bank & 0.10592582 & 12.94509649 & 2.29143 & -2.33463 \\
\hline FMCG & Hindustan Uniliver & 1.97844496 & 6.013653201 & 0.603051 & 1.336149 \\
\hline FMCG & Dabur India Ltd & 1.98474155 & 4.836329718 & 0.731937 & 1.205171 \\
\hline FMCG & Colgate & 0.60608088 & 8.300784566 & 0.402431 & 0.17746 \\
\hline FMCG & ITC & 0.58274091 & 6.581346939 & 0.534517 & 0.013439 \\
\hline
\end{tabular}


IRA-International Joumal of Management E' Social Sciences

\begin{tabular}{|c|c|c|c|c|c|}
\hline FMCG & Britannia & 3.56936324 & 7.573942149 & 0.497972 & 3.038984 \\
\hline Real estate & DLF & 1.1770728 & 14.14688366 & 2.092421 & -1.05152 \\
\hline Real estate & Unitech & 0.5543911 & 21.66737911 & 3.231273 & -2.88717 \\
\hline Real estate & Jaypeeinfratech & 0.52189058 & 19.87482252 & 1.472848 & -1.04681 \\
\hline Real estate & Godrej Properties & 0.96726036 & 11.08114308 & 1.234456 & -0.34753 \\
\hline Real estate & India bulls & 2.97445903 & 17.00678346 & 2.556786 & 0.251281 \\
\hline IT & TCS & 1.53214041 & 6.286544415 & 0.342055 & 1.167825 \\
\hline IT & Infosys & -0.29758981 & 11.73437185 & 0.801337 & -1.15108 \\
\hline IT & Wipro & 0.23374162 & 9.530209436 & 0.441209 & -0.23618 \\
\hline IT & HCL & 1.62126564 & 9.264094471 & 0.390771 & 1.205064 \\
\hline IT & Tech Mahindra & 1.12472984 & 12.43595439 & 0.961095 & 0.101088 \\
\hline Telecom & AIRTEL & 0.78358251 & 8.684961295 & 1.059676 & -0.34506 \\
\hline Telecom & Idea & 0.66894639 & 11.07685505 & 0.749441 & -0.12927 \\
\hline Telecom & Relaincecomm & 0.83589543 & 28.00463135 & 2.174673 & -1.4803 \\
\hline Telecom & Tata com & 1.8670027 & 9.489404401 & 1.215138 & 0.572785 \\
\hline Telecom & MTNL & 0.90605853 & 15.9510888 & 1.722337 & -0.92837 \\
\hline Textile Exports & Mandhana textiles & -2.34894472 & 18.95943855 & 0.150913 & -2.50968 \\
\hline Textile Exports & Bombay Dying & 1.49462966 & 18.60588407 & 2.056117 & -0.6953 \\
\hline Textile Exports & Bombay Rayon & -0.79658596 & 11.93450673 & 0.409776 & -1.23303 \\
\hline Textile Exports & Raymond Ltd & 2.13681169 & 10.34121768 & 1.25745 & 0.797529 \\
\hline Textile Exports & Sutlej textiles & 2.0548646 & 15.50572754 & 1.113106 & 0.869319 \\
\hline Power Industry & JSW Energy & 1.50729823 & 12.65565317 & 2.082478 & -0.7107 \\
\hline Power Industry & NHPC & 0.92459012 & 9.177450646 & 1.088422 & -0.23466 \\
\hline Power Industry & NTPC & 0.25921474 & 7.432983423 & 0.896117 & -0.69522 \\
\hline Power Industry & Reliance power & 0.69175022 & 9.202532595 & 1.154866 & -0.53827 \\
\hline Power Industry & Power grid & 1.0367712 & 5.601910141 & 0.81511 & 0.168615 \\
\hline Entertainment & Zee entertains & 2.37001314 & 6.609617875 & 0.923551 & 1.386359 \\
\hline Entertainment & TV 18 Broad cast & 1.84383915 & 14.04396027 & 2.040363 & -0.32931 \\
\hline Entertainment & Dish TV & 0.79562519 & 11.04083066 & 1.6957 & -1.01043 \\
\hline Entertainment & PVR Ltd & 3.75095001 & 9.486408323 & 0.773725 & 2.926873 \\
\hline Entertainment & Hathway Cable & 0.20521828 & 15.20497091 & 0.736408 & -0.57911 \\
\hline
\end{tabular}


Graph1: Showing the Risk and Return of the stocks from Different selected sectors
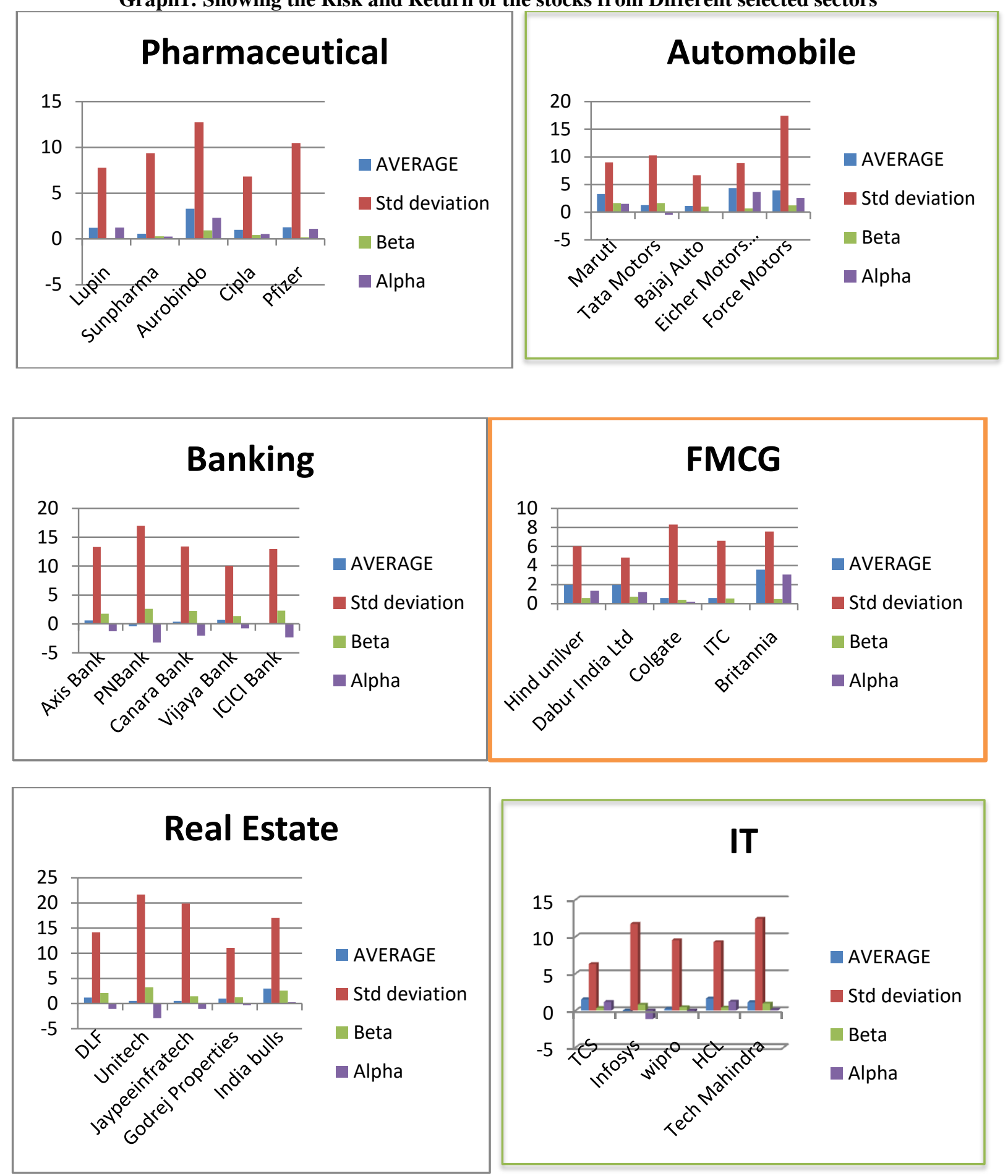

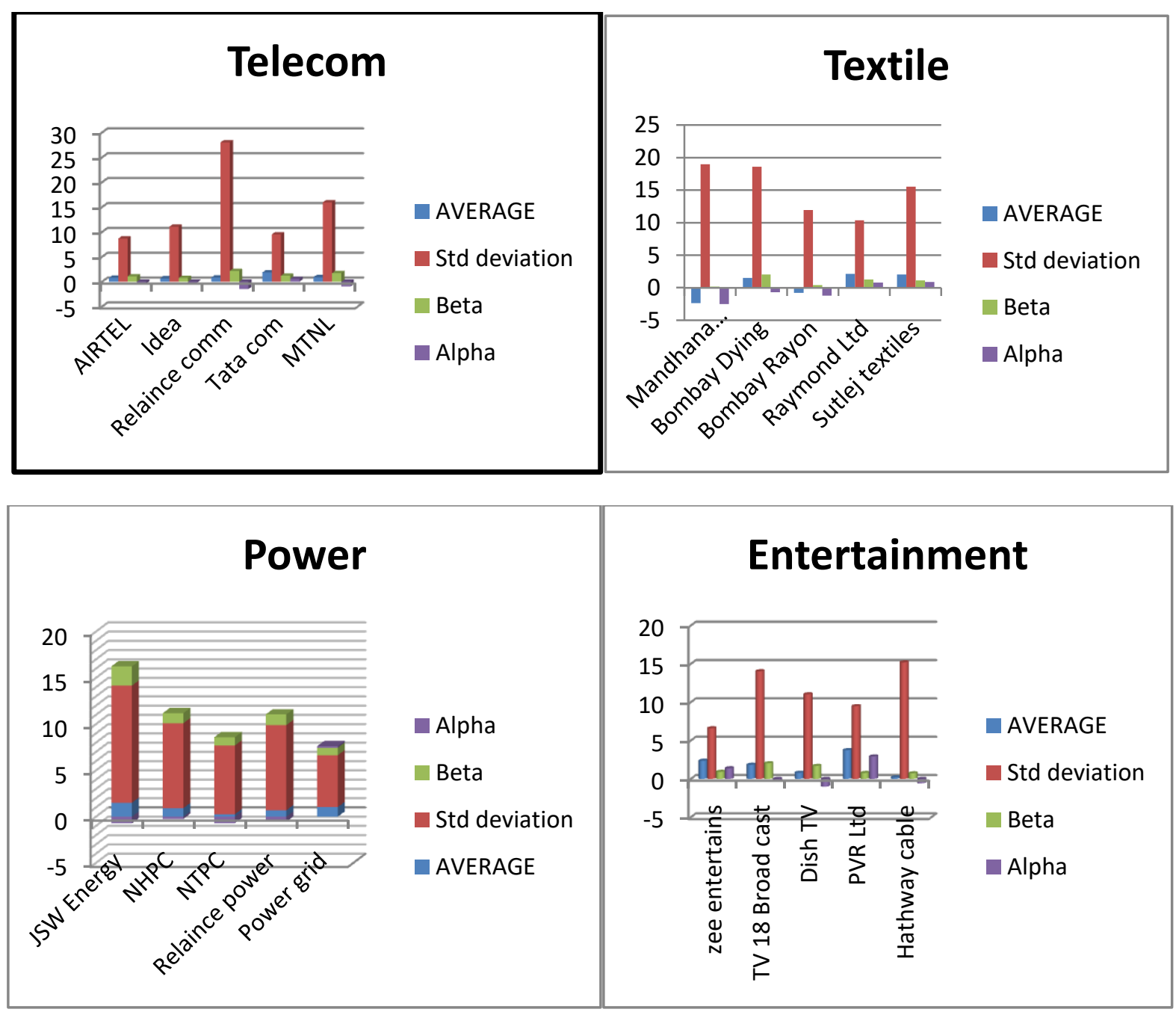

Table 2: Showing the Industry-wise Correlation Analysis

1.Pharmaceutical Industry

\begin{tabular}{lrrrrr}
\hline & \multicolumn{5}{c}{ Sun } \\
LUPIN & Pharma & Aurobindo & Cipla & Pfizer \\
\hline LUPIN & 1 & & & & \\
Sun Pharma & 0.391917548 & 1 & & & \\
Aurobindo & 0.188937051 & 0.259319 & 1 & & \\
Cipla & 0.26372081 & 0.219718 & 0.187565 & 1 & \\
Pfizer & 0.021633789 & 0.069369 & 0.20052 & 0.142928 & 1 \\
\hline
\end{tabular}


2. Automobile Industry

\begin{tabular}{lrrrrr}
\hline & & & & Eicher \\
& & Tata & Motors & Force \\
Maruti & Motors & Bajaj Auto & Motors \\
\hline Maruti & 1 & & & & \\
Tata Motors & 0.418368 & 1 & & & \\
Bajaj Auto & 0.431592 & 0.441461 & 1 & & \\
Eicher Motors & & & & & \\
Ltd & 0.292044 & 0.283609 & 0.2579111 & & 1 \\
Force Motors & 0.378725 & 0.272074 & 0.1868422 & 0.221012 & 1 \\
\hline
\end{tabular}

\section{Banking Industry}

\begin{tabular}{lrrrrr}
\hline & \multicolumn{1}{c}{$\begin{array}{c}\text { Axis } \\
\text { Bank }\end{array}$} & PNBank & $\begin{array}{c}\text { Canara } \\
\text { Bank }\end{array}$ & $\begin{array}{c}\text { Vijaya } \\
\text { Bank }\end{array}$ & $\begin{array}{c}\text { ICICI } \\
\text { Bank }\end{array}$ \\
\hline $\begin{array}{l}\text { Axis Bank } \\
\text { PNBank }\end{array}$ & 0.311255 & & & & \\
$\begin{array}{l}\text { Canara } \\
\text { Bank }\end{array}$ & 0.570271 & 0.647853 & 1 & & \\
$\begin{array}{l}\text { Vijaya } \\
\text { Bank }\end{array}$ & 0.441047 & 0.555628 & 0.676005 & & \\
$\begin{array}{l}\text { ICICI } \\
\text { Bank }\end{array}$ & 0.3103 & 0.763171 & 0.407949 & 0.337236 & \\
\hline
\end{tabular}

\section{FMCG Industry}

\begin{tabular}{lrrrrr}
\hline & $\begin{array}{c}\text { Hind } \\
\text { Unilever }\end{array}$ & $\begin{array}{c}\text { Dabur } \\
\text { India Ltd }\end{array}$ & Colgate & ITC & Britannia \\
\hline $\begin{array}{l}\text { Hind Unilever } \\
\text { Dabur India }\end{array}$ & 1 & & & & \\
Ltd & 0.465743 & 1 & & & \\
Colgate & 0.36125 & 0.148 & 1 & & \\
ITC & 0.246101 & 0.324801 & 0.123587 & & \\
Britannia & 0.166228 & 0.349776 & 0.181292 & 0.075075 & 1 \\
\hline
\end{tabular}

\section{Real Estate Industry}

\begin{tabular}{lrrrrr}
\hline & \multicolumn{1}{c}{ DLF } & Unitech & $\begin{array}{c}\text { Jaypee } \\
\text { Infratech }\end{array}$ & $\begin{array}{c}\text { Godrej } \\
\text { Properties }\end{array}$ & $\begin{array}{c}\text { India } \\
\text { Bulls }\end{array}$ \\
\hline DLF & 1 & & & & \\
Unitech & 0.539770515 & 1 & & & \\
Jaypee infratech & 0.481954531 & 0.654987 & 1 & & \\
Godrej & & & & & \\
Properties & 0.411762297 & 0.34711 & 0.139703 & & 1 \\
India Bulls & 0.544449204 & 0.456352 & 0.333021 & 0.423925 & \\
\hline
\end{tabular}


6. IT Industry

\begin{tabular}{lrrrrr}
\hline & \multicolumn{1}{c}{ TCS } & \multicolumn{1}{c}{ Infosys } & Wipro & HCL & Mahindra \\
\hline TCS & 1 & & & & \\
Infosys & 0.501239 & 1 & & & \\
Wipro & 0.585801 & 0.451778421 & 1 & & \\
HCL & 0.490281 & 0.398100367 & 0.430463 & 1 & \\
Tech & & & & & \\
Mahindra & 0.330118 & 0.329980554 & 0.290479 & 0.652072 & 1 \\
\hline
\end{tabular}

7. Telecom Industry

\begin{tabular}{lrrrrr}
\hline & \multicolumn{5}{c}{ Relaince } \\
AIRTEL & Idea & comm & Tata com & MTNL \\
\hline AIRTEL & 1 & & & & \\
$\begin{array}{l}\text { Idea } \\
\text { Relaince }\end{array}$ & 0.678013 & 1 & & & \\
comm & 0.305147 & 0.345491 & 1 & 1 & \\
Tata com & 0.138972 & 0.064994 & 0.0428 & & \\
MTNL & 0.076164 & 0.014509 & 0.287439 & 0.280623 & 1 \\
\hline
\end{tabular}

8. Textile Industry

\begin{tabular}{lrrrrr}
\hline & $\begin{array}{c}\text { Mandhana } \\
\text { textiles }\end{array}$ & $\begin{array}{c}\text { Bombay } \\
\text { Dying }\end{array}$ & $\begin{array}{c}\text { Bombay } \\
\text { Rayon }\end{array}$ & $\begin{array}{c}\text { Raymond } \\
\text { Ltd }\end{array}$ & $\begin{array}{c}\text { Sutlej } \\
\text { textiles }\end{array}$ \\
\hline Mandhana textiles & 1 & & & & \\
Bombay Dying & -0.06168 & 1 & & & \\
Bombay Rayon & -0.23294 & -0.07318 & 1 & & \\
Raymond Ltd & -0.10508 & 0.514126 & 0.008048 & 1 & \\
Sutlej textiles & -0.0083 & -0.10813 & 0.112259 & 0.18122 & 1 \\
\hline
\end{tabular}

\section{Power Industry}

\begin{tabular}{lrrrrr}
\hline & $\begin{array}{c}\text { JSW } \\
\text { Energy }\end{array}$ & NHPC & NTPC & $\begin{array}{c}\text { Relaince } \\
\text { power }\end{array}$ & $\begin{array}{c}\text { Power } \\
\text { grid }\end{array}$ \\
\hline JSW Energy & 1 & & & & \\
NHPC & 0.498426 & 1 & & & \\
NTPC & 0.489132 & 0.586803 & 1 & & \\
$\begin{array}{l}\text { Relaince } \\
\text { power }\end{array}$ & 0.216728 & 0.321187 & 0.283763 & 1 & \\
Power grid & 0.394486 & 0.434311 & 0.628832 & 0.249495 & 1 \\
\hline
\end{tabular}




\section{Entertainment Industry}

\begin{tabular}{|c|c|c|c|c|c|}
\hline & $\begin{array}{c}\text { zee } \\
\text { entertains }\end{array}$ & $\begin{array}{c}\text { TV } 18 \\
\text { Broad } \\
\text { cast }\end{array}$ & Dish TV & PVR Ltd & $\begin{array}{c}\text { Hathway } \\
\text { cable }\end{array}$ \\
\hline $\begin{array}{l}\text { zee entertains } \\
\text { TV } 18 \text { Broad } \\
\text { cast }\end{array}$ & 0.237636 & 1 & & & \\
\hline Dish TV & 0.460157 & 0.40558 & 1 & & \\
\hline PVR Ltd & 0.195904 & 0.195871 & 0.318259 & 1 & \\
\hline Hathway cable & 0.198544 & 0.251574 & 0.15614 & 0.203122 & 1 \\
\hline
\end{tabular}

The above analysis indicates a positive correlation among all the companies except Textile indicating the assets to be risky. From the above sector-wise correlation analysis, it is evident that there is a negative correlation between Mandana Textiles and Bombay Dying and Bombay rayon to an extent of -0.06168 and -0.10508 , it is also evident that there is a negative correlation between Bombay rayon and Bombay dying.

The above indicates a further study in the construction of a portfolio using the blend of all the sectors. The present study focuses on the sector than the blend of all the sectors and based on the sectors selected, a portfolio is constructed.

\section{Construction of a Portfolio based on Harry Markowitz Model}

Harry Markowitz has identified the effect of diversification in the minimization of risk by coining " do not put all the eggs in one basket" Harry Markowitz has developed a formulae for the construction of a portfolio which is used by majority of Mutual Fund houses and a large retail and institutional investors in the process of minimization of risk. Harry Markowitz formula for expected return and risk is shown below and applied for the construction and decision making based on constructed portfolio.

\section{Expected Return \\ $\mathbf{E R p}=\mathbf{W A} * \mathbf{R A}+\mathbf{W B} * \mathbf{R B}+\mathbf{W C} * \mathbf{R C}+\mathbf{W D} * \mathbf{R D}+\mathbf{W E} * \mathbf{R E}$}

The above formula is applied for five stocks and it can be extended for $n$ number of stocks selected by the investor. Equal weights (proportion of Investment) is assumed for the calculation of Expected return and Risk.

\section{Portfolio risk}

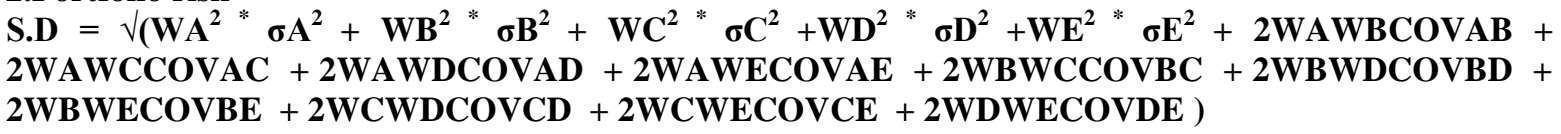

\section{Pharmaceutical Company}

Weightage Company: $A=20, B=20, C=20, D=25$ and $E=20$.

Expected Return $=\mathbf{1 . 4 7 6 3 8}$

Standard deviation $=\mathbf{7 . 1 3 9 5}$

\section{2: Automobile}

Weightage Company: $A=20, B=20, C=20, D=25$ and $E=20$.

Expected Return $=\mathbf{2 . 8 0 4 1}$

Standard deviation $=\mathbf{8 . 2 1 3 1}$

3: Bank

Weightage Company: $A=20, B=20, C=20, D=25$ and $E=20$.

Expected Return $=\mathbf{0 . 2 8 6 4}$

Standard deviation $=\mathbf{1 1 . 2 4 5 9}$ 
4: FMCG

Weightage Company: $A=20, B=20, C=20, D=25$ and $E=20$.

Expected Return $=1.74512$

Standard deviation $=\mathbf{5 . 8 7 5 6 8}$

\section{5: Real Estate}

Weightage Company: $A=20, B=20, C=20, D=25$ and $E=20$.

Expected Return $=1.239032$

Standard deviation $=12.8799$

6: IT

Weightage Company: $A=20, B=20, C=20, D=25$ and $E=20$.

Expected Return $=\mathbf{0 . 8 4 2 8 5}$

Standard deviation $=\mathbf{8 . 4 9 7 8 9}$

7: Telecom

Weightage Company: $A=20, B=20, C=20, D=25$ and $E=20$.

Expected return $=\mathbf{0 . 6 3 8 8 7 1}$

Standard deviation $=9.14733$

8: Textile Export

Weightage Company: $A=20, B=20, C=20, D=25$ and $E=20$.

Expected return $=\mathbf{0 . 5 0 8 1 6 3 4}$

Standard deviation $=\mathbf{7 . 7 8 8 1 6}$

9: Power Industry

Weightage Company: $A=20, B=20, C=20, D=25$ and $E=20$.

Expected return $=0.8839248$

Standard deviation $=\mathbf{7 . 7 0 2 0}$

10: Entertainment

Weightage Company: $A=20, B=20, C=20, D=25$ and $E=20$.

Expected return $=1.793129$

Standard deviation $=8.38496$

Table 2: Showing the Portfolio Return and Portfolio Risk of various selected Industries

\begin{tabular}{|c|c|c|c|c|c|}
\hline Portfolio & $\begin{array}{c}\text { Portfolio } \\
\text { Return }\end{array}$ & $\begin{array}{c}\text { Portfolio } \\
\text { Risk }\end{array}$ & Portfolio & $\begin{array}{c}\text { Portfolio } \\
\text { Return }\end{array}$ & $\begin{array}{c}\text { Portfolio } \\
\text { Risk }\end{array}$ \\
\hline Pharmaceutical & 1.47638 & 7.1395 & IT & 0.84285 & 8.49789 \\
\hline Automobile & 2.8041 & 8.2131 & Telecom & 0.63887 & 9.14733 \\
\hline Banking & 0.2864 & 11.2459 & Textile & 0.50816 & 7.78816 \\
\hline FMCG & 1.74512 & 5.87568 & Power & 0.88393 & 7.702 \\
\hline Real estate & 1.23903 & 12.8799 & Entertainment & 1.79313 & 8.38496 \\
\hline
\end{tabular}


Graph2: Showing the portfolio Return and Portfolio Risk of various selected Industries

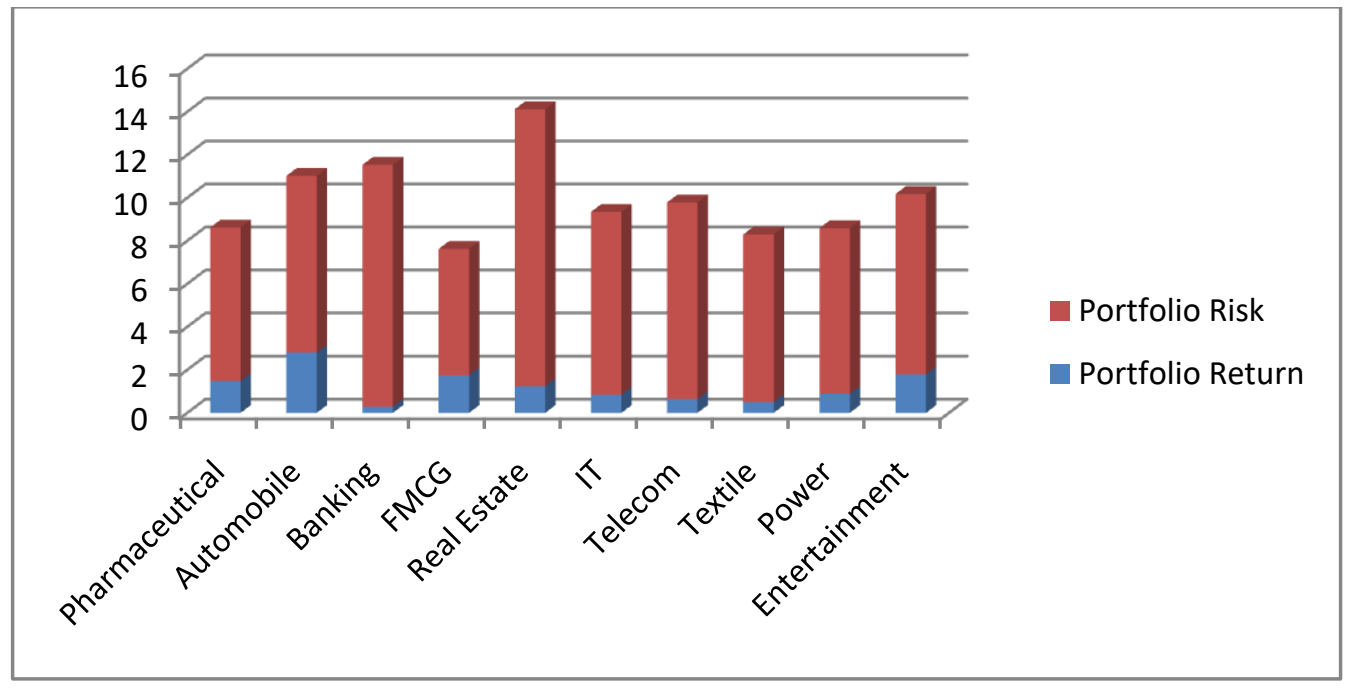

Findings

1. PNB, Canara Bank, India bulls, DLF, JSW energy, and TV18 broadcast has shown a beta value of $2.268453,2.64051,2.556786,2.082478$ and 2.040363 respectively indicating the riskiness in the stocks towards a market action.

2. Dabur has the lowest standard deviation of 4.836329718 with an average return of 1.98474155 compared to all the stocks selected for the study.

3. The above analysis proves that the Automobile sector and Entertainment sector is giving a maximum return of 2.8041 and 1.793129 with a moderate rate of risk of 8.2131 and 8.38496 respectively.

4. FMCG sector has a minimum portfolio risk of 5.87568 with a decent return of 1.74512 proving to be the optimum portfolio for long term investors.

5. Except for the Textile sector, all other sectors had positive correlation indicating the stock not to be a part of one portfolio where it becomes difficult in the diversification of the risk.

6. It is found that with the application of Harry Markowitz model, FMCG Sector has least portfolio risk compared to other sectors. The next least portfolio risk is found in Pharmaceutical followed by Power, Textile, Automobile, Entertainment, IT, Telecom, Banking, and Real Estate.

7. From the table 1 it is found that Companies like Force Motors, Tata Motors, Maruti individually has highest standard deviations of $17.42761493,10.29204526,9.026482606$ whereas a combination of it will diversify the risk of the investors as it is pointed in table 2 which expresses to be 1.793129 which proved to be the optimal portfolio as specified in the above finding.

8. Pharmaceutical, Automobile and IT sectors have the lowest beta values acting as a defensive platform for the investors.

\section{Conclusion}

The study on Risk and Return analysis proved to be effective for all long term investors and short term traders and fund houses to efficiently select the portfolios for obtaining a better risk-reward ratio. The Correlation with a blend of all the sectors can be an extension in the present study whereas the correlation sector-wise is analysed for checking the directional movement of the stocks which is used by most of the analysts for the selection of the stocks and Portfolio and that the Risk and Return will help most of the investors to categorize the stocks as aggressive and Defensive. The Harry Markowitz Portfolio construction technique is used for the computation of Risk and Return and the selection of the portfolio based on the Portfolio Risk and Portfolio Return. 


\section{References}

[1]. Anindita, B. B. (2015). Risk and Return Relationship- An Empirical Study of BSE Sensex Companies in India. Universal Journal of Accounting and Finance, PP 45-51.

[2]. B.Ashturkar, A. M. (August 2015). An Evaluation and Analysis of the Risk/Return Profile of Selected Banks. International Journal of Enhanced Research in Science, Technology, and Engineering, PP 37-43.

[3]. Das Gupta, R. (2017). Behavioural Implications of Risk-Return Associations: An Application of Prospect Theory on CNX NIFTY Companies. Australasian Accounting Business and Finance Journal, PP 103-126.

[4]. Das, s. K. (June 2014). Construction of Portfolio Using Sharpe Index Model With Reference to FMCG Industry in India. Adhyanan: A Journal of Management Sciences, PP 77- 77-91.

[5]. Gautam Bandyophyay, A. D. (March 2016). Measurement of Risk Vs Return of Indian Sectoral Indices. Journal of Advanced Management Science, PP 106-111.

[6]. Goalakrishnan, A. V. (2017). A study on Risk-Return Analysis of Pharm. Imperial Journal of Interdisciplinary Research, PP 1869-1874.

[7]. M.Ravichandran, T. a. (April 2016). A study on Performance of Risk and Return on Selected Mutual Funds. International Journal for Innovative Research in Science and Technology, 176-178.

[8]. Maheshwari, S. a. (2015). The Long-Run Return Reversal Effect: A Re-Examination in the Indian Stock Market. Journal of Business Inquiry: Research, Education and Applications, PP 59- 78.

[9]. Maniar, H. (Jan-Apr 2017). Scenario of Commodity Risk Management Practices used by Indian Construction Companies. Journal of Modern Project Management, PP 74-85.

[10]. Nidhi, T. D. (July 2015). A Sector Wise Empirical Analysis of Risk-Return Relationship . International Journal of Management Research and Review, PP 588-593.

[11]. Pamene, A. E. (2014). An Analysis of the Relationship between Risk and Expected Return in BRVM Stock Exchange: Test of the CAPM. www.sciedu.ca/rwe, PP 13-28.

[12]. Pandey, A. (Apr-Jun 2005). Volatility Models and their Performance in Indian Capital Markets. Vikalpa: The Journal of Decision Makers, PP 27-46.

[13]. Pandian Punithavathy, D. J. (March 2008). Return and Risk Analysis of Indian Information Technology sector Stocks. ICFAI Journal of Financial Risk Management , PP 41-49.

[14]. PVikkraman, V. P. (January- March 2009). A study on Risk and Return analysis of Automobile industry in India. Journal Of Contemporary Research In Management, PP 35-40.

[15]. Rakesh, D. R. (Jul-Dec 2006). Risk- Return Relationship and Effect of Diversification on Non-Market Risk: Application of Market Index Model In Indian Stock Market. Journal of Financial Management and Analysis , PP 2231.

[16]. S, K. R. (Jan-Mar 2011). Distribution of Risk and Return: A test of Normaility in Indian stock Market. South Asian Journal of Management, PP 109-118.

[17]. Sharma, A. (February 2015). Return and Risk Analysis of Selected Sector Specific Mutual Funds in India. International Journal of Engineering and Management Research, PP 06-10.

[18]. Sudhakar, A. R. (Dec 2016). Risk and Return Analysis of Select PSBs. Clear International Journal of Research in Commerce and Management, PP 33-44.

[19]. Swathiga, P. D. (2017). A study on relationship between risk and return analysis of selected stocks on NSE using capital asset pricing model. International Journal of Applied Research, PP 375-378.

[20]. T, M. T. (Jul-Dec 2006). An Empirical Testing of Risk Factors in the returns on Indian Capital Market. Decision, PP 93-110.

[21]. Walia, N. a. (2011). A Comparitive Analysis of Performance, Investment Styles, and Risk and Return Associated with Indian Mutual Funds. Journal of Index Investing, PP 86-95.

Weblinks:

[1]. https://www.nseindia.com/products/content/equities/equities/eq_security.htm

[2]. https://www.bseindia.com/markets/equity/EQReports/StockPrcHistori.aspx?expandable=7\&flag0

[3]. https://www.bseindia.com/indices/IndexArchiveData.aspx?expandable=1 